\title{
Kegiatan Montase dalam Meningkatkan Kecerdasan Visual Spasial Anak Usia Dini
}

\author{
Azlin Atika Putri ${ }^{1 凶}$ \\ Pendidikan Guru Pendidikan Anak Usia Dini, Universitas Lancang Kuning, Indonesia \\ DOI: $10.31004 /$ obsesi.v6i2.1624
}

\begin{abstract}
Abstrak
Studi pendahuluan terhadap subjek penelitian, bahwa sebagian besar anak belum memiliki kemampuan visual spasial yang baik, yang ditunjukkan dari kesulitan-kesulitan anak dalam hal visual spasial pada saat belajar. Penelitian ini bertujuan untuk meningkatkan kecerdasan visual spasial anak melalui kegiatan montase. Metodologi penelitian yang dilakukan adalah Action research dengan model Kemmis dan Mc Taggart, melalui dua siklus yang terdiri dari delapan pertemuan pada siklus I dan enam kali pertemuan pada siklus II yang meliputi tahap perencanaan, tindakan, observasi dan refleksi. Subjek penelitian adalah anak kelompok B TK FKIP UNRI Kota Pekanbaru provinsi Riau. Analisis data menggunakan analisis kuantitatif dan kualitatif. Hasil penelitian ini menunjukkan adanya peningkatan kecerdasan visual spasial anak melalui kegiatan montase. Rata-rata skor kecerdasan visual spasial pra siklus sebesar 30,06, kemudian mengalami peningkatan menjadi 38,46 pada akhir siklus I dan mengalami peningkatan kembali menjadi 47,53 pada akhir siklus II.
\end{abstract}

Kata Kunci: montase; kecerdasan visual; kecerdasan spasial; kecerdasan visual spasial; anak usia dini

\begin{abstract}
Preliminary study of research subjects, that most children do not have good visual spatial abilities, which is indicated by the difficulties of children in terms of visual spatial on class. This study aims to improve children's visual-spatial intelligence through montage activities. The research methodology is Action research with the Kemmis and Mc Taggart model, through two cycles consisting of eight meetings in the first cycle and six meetings in the second cycle which includes the stages of planning, action, observation and reflection. The research subjects were children of group B TK FKIP UNRI Pekanbaru City, Riau province. Data analysis used quantitative and qualitative analysis. The results of this study indicate an increase in children's visual spatial intelligence through montage activities. The average pre-cycle visual-spatial intelligence score was 30.06, then increased to 38.46 at the end of the first cycle and increased again to 47.53 at the end of the second cycle.
\end{abstract}

Keywords: activities montage; visual-spatial intelligence; early childhood

Copyright (c) 2021 Azlin Atika Putri

$\square$ Corresponding author:

Email Address : azlin@unilak.ac.id (Pekanbaru, Indonesia)

Received 10 February 2021, Accepted 27 July 2021, Published 29 July 2021 


\section{PENDAHULUAN}

Setiap manusia memiliki kecerdasan dengan kadar perkembangan yang berbeda. Tingkat kecerdasan dapat membantu seseorang dalam menghadapi berbagai permasalahan yang muncul dalam kehidupannya. Pengembangan kecerdasan akan lebih baik jika dilakukan sedini mungkin sejak anak dilahirkan melalui pemberian stimulasi pada kelima panca indranya. Kecerdasan visual spasial merupakan salah satu yang harus dikembangkan. Kecerdasan yang berhubungan erat dengan kemampuan untuk memvisualisasikan gambar yang ada di dalam pikiran, (Mutiah \& Srikandi, 2021).

Berdasarkan hasil pengamatan peneliti pada TK FKIP UNRI anak usia 5-6 tahun khususnya yang berada pada kelompok B, peneliti menemukan bahwa anak kelompok B belum memiliki kemampuan visual spasial yang baik. Dari jumlah keseluruhan anak kelompok B yaitu 15 anak ketika melakukan kegiatan visual spasial terlihat hampir keseluruhan anak belum memiliki kemampuan visual spasial yang baik. Hal ini ditunjukkan dengan: 1) anak kurang senang menggambar menggunakan gagasannya, 2) anak kesulitan mengklasifikasikan benda berdasarkan warna dan bentuk, 3) anak sering tidak tepat ketika menempel atau memadukan gambar, dan 4) kurangnya pemahaman anak dalam mengkonstruksi gambar-gambar dua dimensi.

kecerdasan visual spasial dikemukakan oleh (Chairilsyah, 2020) yang menyatakan bahwa spatial intelligence are capacities to perceive the visual world accurately, to perform transformations and modification upon one's initial perceptions and to be able to re-create aspects of one's visual experience even in the absence of relevant physical stimuli. Gardner dalam hal ini menjelaskan bahwa kecerdasan visual spasial merupakan kapasitas atau kemampuan untuk merasakan dunia visual secara akurat, untuk membentuk suatu gambaran mental tentang tata ruang atau menghadirkan dunia mengenai ruang secara internal di dalam pikirannya serta memodifikasi sesuatu. Kecerdasan visual spasial membantu seseorang untuk dapat mencipta dari pengalaman visual seseorang walau tanpa adanya rangsangan.

Hal ini diperkuat oleh (Armstrong, 2009) bahwa the ability to perceive the visual-spatial world accurately (e.g., as a hunter, scout, or guide) and to perform transformations upon those perceptions (e.g., as an interior decorator, architect, artist, or inventor). This intelligence involves sensitivity to color, line, shape, form, space, and the relationships that exist between these elements. It includes the capacity to visualize, to graphically represent visual or spatial ideas, and to orient oneself appropriately in a spatial matrix". Pernyataan tersebut menjelaskan bahwa seseorang yang cerdas dalam visual spasial memiliki kepekaan terhadap warna, garis-garis, bentuk-bentuk, ruang dan bangunan serta dapat memahami warna, arah dan ruang secara akurat. Kemampuan yang diperlukan dalam dunia visual spasial melibatkan kepekaan terhadap warna, garis, bentuk, ruang, dan hubungan-hubungan yang ada di antara unsur-unsur ini.

Menurut Sonowat dan Gogri (2008: 62) bahwasanya this intelligence involves the ability to think in three dimensions and use mental imagery, spatial reasoning, image manipulations, graphic and artistic skills, and active imagination. Menurutnya kecerdasan visual spasial merupakan kecerdasan yang melibatkan kemampuan untuk berpikir dalam tiga dimensi dan menggunakan citra mental, penalaran spasial, manipulasi gambar, grafis dan keterampilan artistik, dan imajinasi aktif. Selanjutnya Menurut Yaumi dan Nurdin (2013: 82) kecerdasan visual spasial adalah kemampuan untuk menginterpretasi dimensi ruang yang tidak dapat dilihat. Sedangkan menurut Lwin dkk (2008:74) bahwa kecerdasan visual spasial adalah kemampuan untuk menerjemahkan gambaran dalam pikiran mereka ke dlam bidang fisik melalui penggambaran, pelukisan, pemahatan, pembangunan, atau pembentukan.

Berdasarkan dari beberapa landasan teori maka dapat disimpulkan bahwa kecerdasan visual spasial merupakan kemampuan seseorang dalam gambar, grafis dan keterampilan artistik, serta imajinasi aktif yang melibatkan kepekaan untuk mengidentifikasi objek atau gambar, memahami hubungan spasial, memodifikasi objek.

Penelitian yang dilakukan oleh Hyangsook (2013) "The Brain and Learning: examining the connection between brain activity, spatial intelligence, and learning outcomes in online visual 
instruction". Penelitian ini membandingkan media 2 dimensi dan 3 dimensi untuk mengetahui kecerdasan visual spasial anak. Hasil penelitiannya menyatakan bahwa "there was a significant interaction between spatial intelligence, depth and movement on recall; for low spatial learners, 2D animation resulted in significantly higher recall than both 2D still frame and 3D animation, and for high spatial learners, 3D animation resulted in significantly higher recall than 3D still frame, and both 2D still frame and 2D animation resulted in close to significantly higher recall than 3D still frame". Salahsatu saran dari penelitiannya adalah "spatial ability from children aged 13 and younger, indicated that, while the subjects showed above average quantitative and verbal ability, their spatial ability showed significant individual differences". Artinya sangat penting mengoptimalkan kecerdasan visual spasial sejak usia dini karena individu cenderung lebih mudah mengingat dan berpikir mengenai media 2D dan 3D pada usia 13 tahun ke bawah.

Selanjutnya Miswanto (2014) mengemukakan bahwa kecerdasan visual spasial sangat mempengaruhi kemampuan kreativitas berpikir anak, Hal ini dibuktikan dengan hasil Fhitung > Ftabel yaitu 14,894 > 4,13 pada taraf 5\% dan Fhitung > Ftabel yaitu 14,894> 7,44 pada taraf $1 \%$. Besar pengaruh kecerdasan visual-spasial terhadap kreativitas berpikir siswa adalah sebesar 30,5\% ( KD $=\mathrm{r} 2 \times 100 \%=0,305 \times 100 \%=30,5 \%)$. Sisanya $69,5 \%$ dipengaruhi oleh variabel lain seperti kecerdasan logika matematika, kecerdasan linguistik, dan kecerdasan lainnya. Adapun saran dari hasil penelitian yang dilakukan oleh Miswanto (2014) adalah "Guru hendaknya mempertimbangkan faktor-faktor yang dapat mempengaruhi hasil belajar siswa, seperti metode pembelajaran terkini yang dapat memanfaatkan seluruh kecerdasan siswa dan dapat mengembangkan kreativitas berpikir siswa sehingga tidak terpaku pada peningkatan beberapa kecerdasan saja".

Berdasarkan paparan hasil penelitian terdahulu, maka perlu adanya penelitian yang bertujuan untuk menghasilkan kecerdasan visual spasial anak usia dini. Dengan karakteristik anak pada usia 5-6 tahun adalah aktif dan imajinatif melalui kegiatan yang menyenangkan, maka salah satu cara mengembangkan kecerdasan visual spasial yang tepat adalah dengan menggunakan kegiatan montase.

Menurut (Muharrar \& Verayanti, 2013) montase adalah karya yang sangat identik dengan guntingan gambar atau biasa juga disebut sebagai karya gunting tempel (cut and paste). Sedangkan menurut (Laliberte, 2020) Montage is art cut and pasting together bits and pieces of printed picture to express simple or sentimental compositions and omamental or decoratives themes. Pendapat Laliberte dan Mogelon dapat diartikan montase adalah seni gunting tempel dengan menyisipkan potongan-potongan gambar yang dikomposisi untuk menjadi suatu cerita sederhana. Menurut (Naibaho et al., 2017) montase yaitu terbentuknya tema baru dari gambar-gambar jadi yang disusun anak-anak menjadi pertimbangan pokok dalam mengevaluasi hasil karyanya. Selanjutnya Menurut (Hajar Pamadhi, 2008) montase adalah mengomposisikan beberapa gambar yang sudah jadi dengan gambar yang sudah jadi lainnya. (Restian, 2020) juga menjelaskan bahwa montase adalah pembelajaran yang memanfaatkan kertas koran, majalah, atau kalender bekas terutama yang berwarna.

Berdasarkan dari beberapa landasan terori maka dapat disimpulkan bahwa montase adalah suatu karya yang mengomposisikan beberapa gambar yang sudah jadi dengan gambar yang sudah jadi lainnya dengan cara menggunting dan menempel dengan menggunakan majalah, koran, kalender, kertas berwarna sehingga menjadi suatu tema ataupun cerita yang baru. Kegiatan montase ini menarik dan menyenangkan bagi anak, sehingga melalui kegiatan montase diharapkan dapat meningkatkan kecerdasan visual spasial anak usia dini. Penelitian terkait mengembangkan kecerdasan visual spasial anak usia dini melalui kegiatan montase belum ditemukan dalam pencarian artikel ilmiah dan pencarian hasil penelitian pada repository online, sehingga peneliti merasa perlu untuk melihat keefektifan kegiatan montase ini dalam meningkatkan kecerdasan visual spasial anak usia dini.

\section{METODOLOGI}


Metode penelitian yang digunakan adalah penelitian tindakan kelas (action research), oleh Kemmis dan Mc. Taggart yang meliputi empat tahapan yaitu: perencanaan, tindakan, pengamatan, dan refleksi (dapat dilihat pada gambar 1). Subjek penelitian yang terlibat pada penelitian ini adalah siswa kelas B yang berusia 5-6 Tahun di TK Universitas Riau yang berjumlah 15 anak. Waktu pelaksanaan penelitian disesuaikan dengan jam aktif proses kegiatan belajar mengajar di TK tersebut. Teknik pengumpulan data yang digunakan adalah berupa non tes yang dilihat hasil pengamatan atau observasi. Instrumen dikembangkan melalui definisi konseptual dan operasional yang menjelaskan bahwa kecerdasan visual spasial adalah skor yang menggambarkan kesanggupan anak dalam mencapai indikator kecerdasan visual spasial. Teknik analisis data yang digunakan adalah kuantitatif deskriptif dan analisis data secara kualitatif. Analisis data kuantitatif disajikan dalam bentuk tabel dan grafik. Sementara analisis data secara kualitatif menggunakan metode (Huberman \& Miles, 2019) yang terdiri dari tiga tahap yaitu reduksi data, display data, dan verifikasi data.

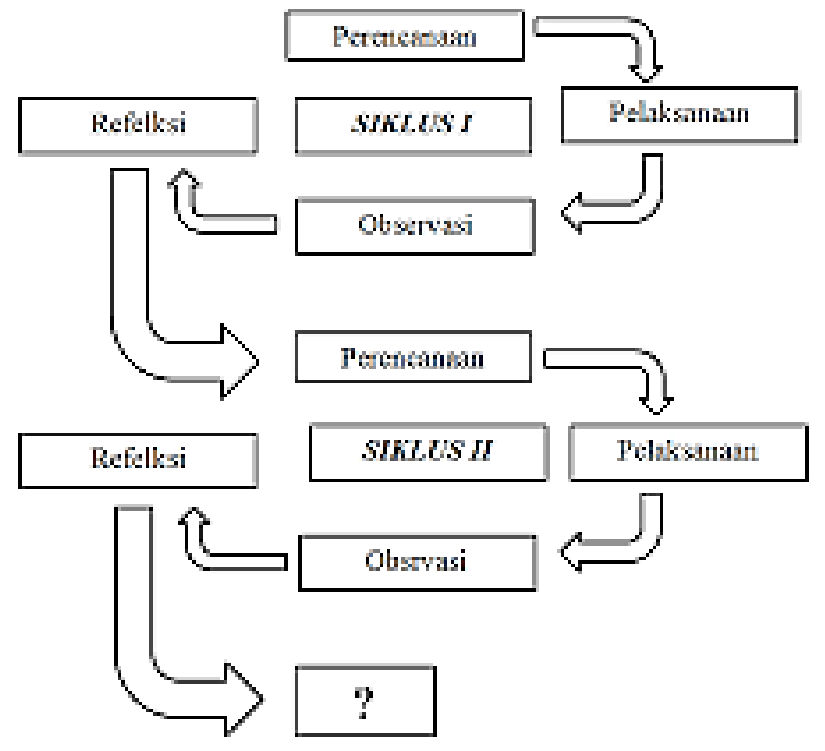

Gambar 1. Siklus Penelitian TIndakan Model Kemmis dan Mc Taggart

\section{HASIL DAN PEMBAHASAN}

Hasil penelitian menunjukkan bahwa kecerdasan visual spasial anak kelompok B TK FKIP UNRI Kota Pekanbaru Provinsi Riau sudah mulai mengalami peningkatan dari prasiklus sampai pada siklus II. Asessmen awal (pra siklus) dilakukan untuk mengetahui kondisi awal kecerdasan visual spasial anak pada kelompok B TK FKIP UNRI Kota Pekanbaru Provinsi Riau. Adapun hasil asessmen awal untuk kecerdasan visual spasial anak sebagaimana pada grafik 1 .

Data pada grafik I menunjukkan rata-rata tingkat capaian perkembangan (TCP) anak pada pra-siklus untuk kecerdasan visual spasial anak. Rata-rata tingkat capaian perkembangan (TCP) anak kelompok B pada pra-siklus sebesar 30,06. Data pada pra-siklus menunjukkan bahwa dari 15 anak hanya 3 anak yang masuk pada kategori mulai berkembang (MB) dan 12 anak masih berada pada kategori belum berkembang (BB). Berdasarkan data di atas dapat digambarkan bahwa skor tingkat capaian perkembangan (TCP) Tertinggi diperoleh oleh APZ sebesar 38, FF sebesar 40, dan ZT sebesar 40, sedangkan skor terendah diperoleh oleh SRP sebesar 22, FMPM sebesar 24, IW sebesar 24, SHS sebesar 24. 


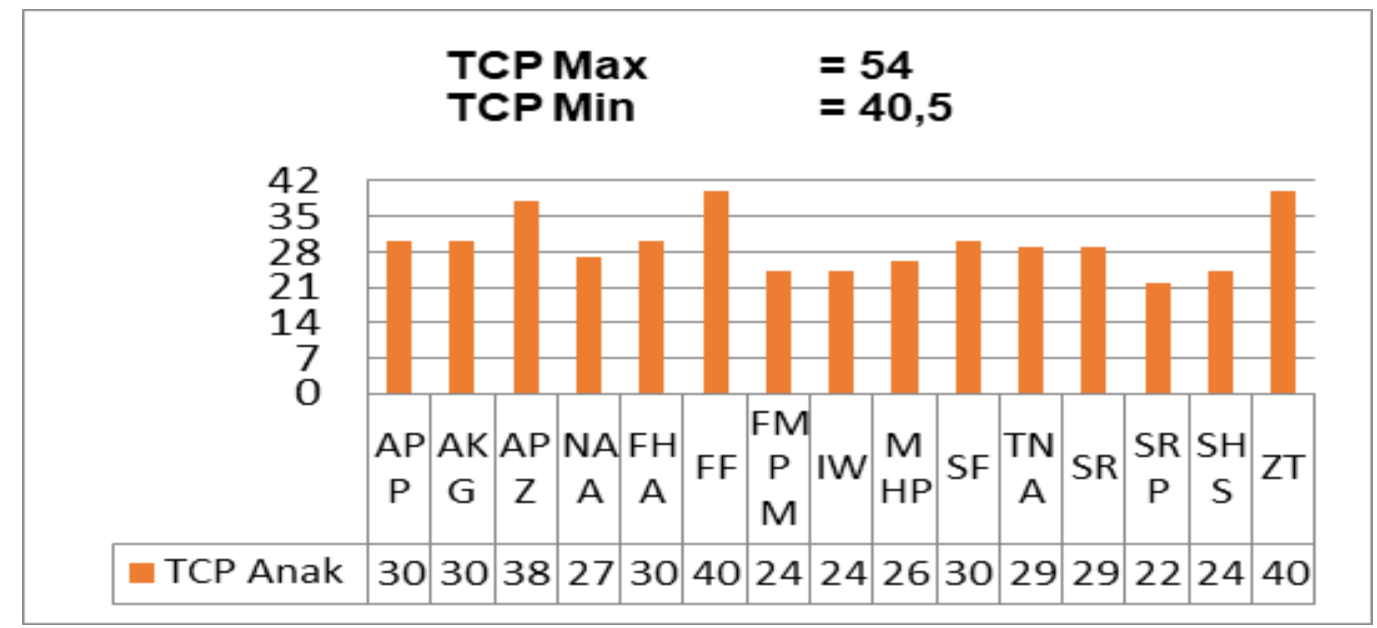

\section{Grafik 1. Hasil Asesmen Awal Kecerdasan Visual Spasial Pada Pra Siklus}

Observasi pada siklus I dilakukan untuk mengetahui skor yang diperoleh anak setelah pemberian tindakan kegiatan montase dalam meningkatkan kecerdasan visual spasial anak. Adapun data observasi pada siklus I sebagaimana grafik 2.

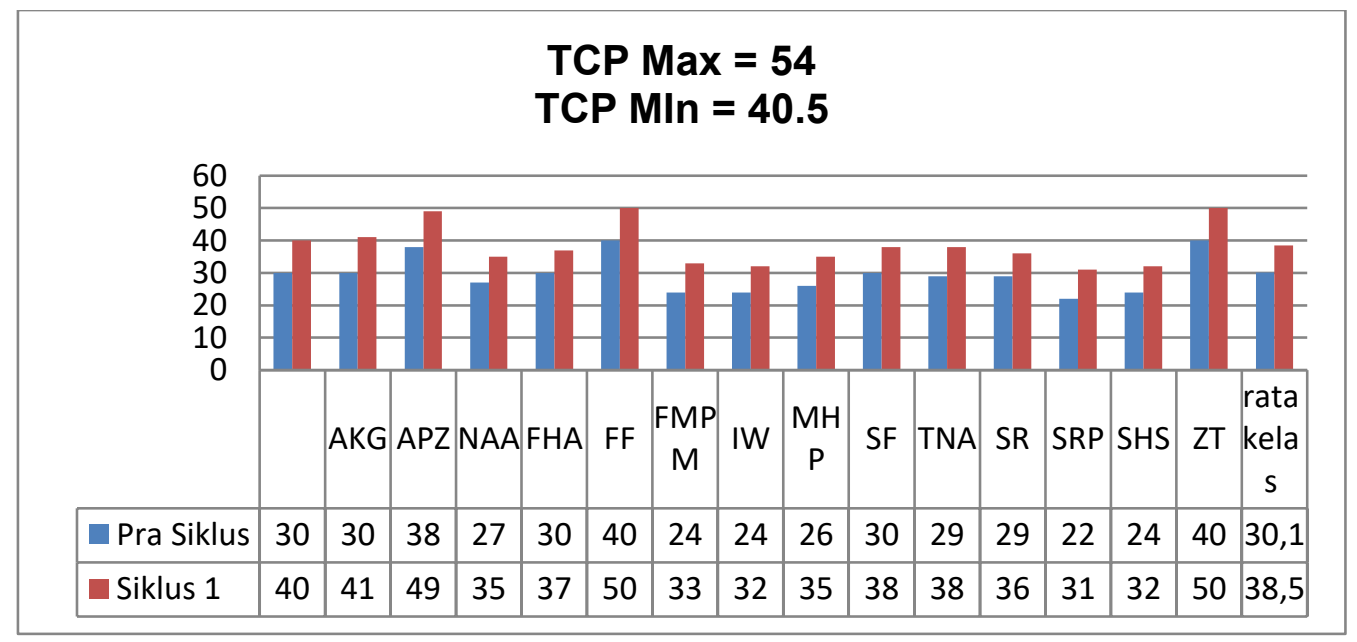

Grafik 2. Data Hasil Asesmen Intervensi Kecerdasan Visual Spasial Pra Siklus - Siklus I

Data pada grafik 2 menunjukkan rata-rata tingkat capaian perkembangan (TCP) anak pada pra-siklus sampai pada siklus I untuk kecerdasan visual spasial anak dari pertemuan pertama sampai kedelapan. Berdasarkan data di atas, kecerdasan viusal spasial anak pada pra-siklus mengalami kenaikan pada siklus I. Hal tersebut ditunjukkan dengan perolehan rata-rata tingkat capaian perkembangan (TCP) kecerdasan visual spasial anak pada pra-siklus sebesar 30,06 dan pada siklus I sebesar 38,46. Tingkat capaian perkembangan tertinggi dari kecerdasan visual spasial diperoleh ananda FF dan ZT dengan nilai sebasar 50 dan terendah diperoleh ananda SRP nilai sebesar 31 dan IW dengan nilai sebesar 32. Data pada siklus I, dari 15 anak ada 3 anak yang masuk pada kategori berkembang sesuai harapan (BSH), dan masih ada 12 anak yang masuk pada kategori mulai berkembang (MB). Dengan demikian persentase kenaikan belum mencapai standar keberhasilan $71 \%$ dari jumlah anak yang mencapai skor di atas TCP minimal sebesar 40,5. Oleh karena itu peneliti dan kolaborator menyepakati untuk melanjutkan pada siklus II. Hal ini dilakukan atas kesepakatan antara peneliti dan kolaborator dengan pertimbangan agar kecerdasan visual spasial anak meningkat sesuai dengan harapan yang telah ditentukan dengan memperbaiki segala kekurangan pada siklus I agar lebih maksimal dan optimal pada tindakan siklus II. 


\section{Siklus II}

Observasi pada siklus II dilakukan untuk mengetahui skor yang diperoleh anak setelah pemberian tindakan berupa kegiatan montase dalam meningkatkan kecerdasan kvisual spasial anak. Adapun data observasi pada siklus II sebagaimana grafik 3.

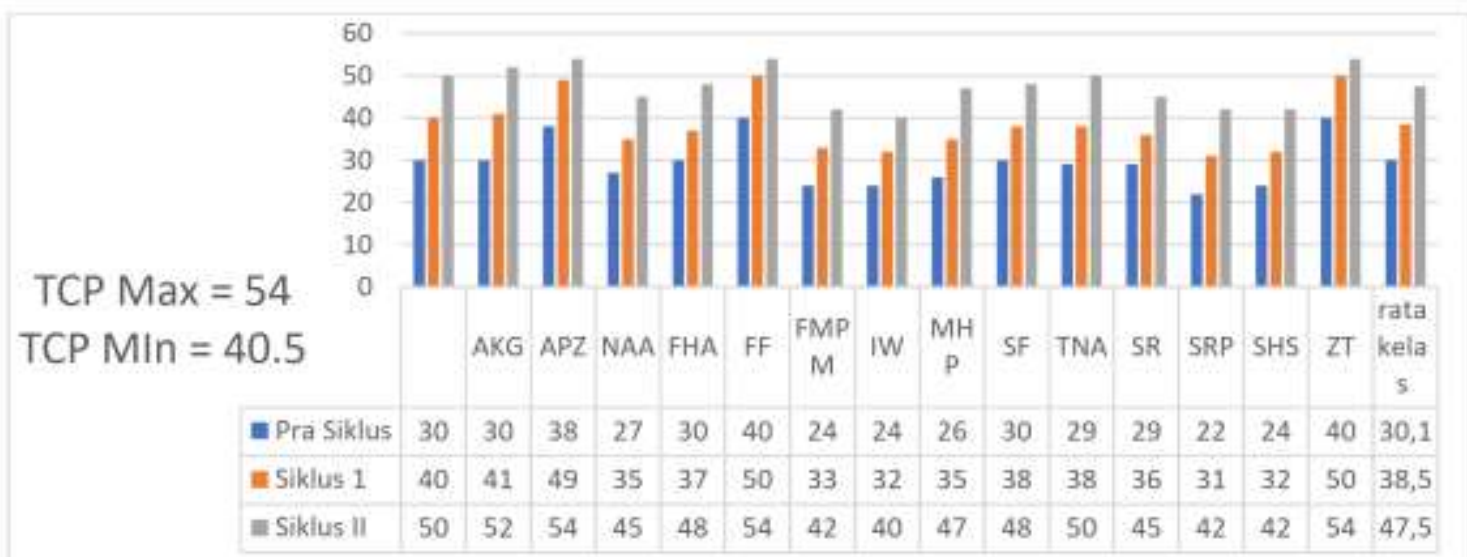

\section{Grafik 3. Hasil Asesmen Intervensi Kecerdan Visual Spasial Anak Pada Pra Siklus, Siklus I dan Siklus II}

Data pada grafik 3 menunjukkan rata-rata tingkat capaian perkembangan (TCP) anak pada pra-siklus sampai pada siklus II untuk kecerdasan visual spasial anak dari pertemuan kesembilan sampai pada pertemuan keempatbelas. Berdasarkan data di atas kecerdasan visual spasial anak pada pra-siklus terus mengalami kenaikan dari siklus I sampai pada siklus II. Hal tersebut ditunjukkan dengan perolehan rata-rata tingkat capaian perkembangan (TCP) kecerdasan visual spasial anak pada pra siklus sebesar 30,06, siklus I sebesar 38,46, dan siklus II sebesar 47,53. Tingkat capaian perkembangan (TCP) tertinggi kecerdasan visual spasial anak pada siklus II diperoleh ananda APZ, FF, dan ZT sebesar 54, sedangkan terendah diperoleh ananda IW sebesar 40, SHS, FMPM, SRP sebesar 42 . Data pada siklus II, dari 15 anak ada 12 anak yang masuk dalam kategori berkembang sesuai harapan (BSH) dan 3 anak yang masih dalam kategori mulai berkembang (MB). Oleh karena itu keseluruhan jumlah anak tidak ada yang masuk pada kategori belum berkembang BB. Dengan demikian persentase kenaikan sudah mencapai standar keberhasilan $71 \%$ menurut Mills dari jumlah anak yang mencapai skor di atas TCP minimal sebesar 40,5 . Dari hasil pencapaian tersebut, maka peneliti dan kolaborator menyepakati bahwa pemberian tindakan sampai pada siklus II.

Berdasarkan hasil analisis data kuantitatif diperoleh persentase total kenaikan observasi sebesar $17.47 \%$ hal tersebut menunjukkan telah terjadi peningkatan persentase kecerdasan visual spasial anak pada pra-siklus, siklus I, hingga siklus II. Pada pra-siklus dan akhir siklus I, perolehan persentase observasi belum terlihat maksimal. Berdasarkan hasil analisis kuantitatif juga terlihat bahwa, pada pra-siklus, siklus I, dan siklus II APZ mendapat skor persentase tertinggi sebesar 54 . FF dan ZT mendapat skor tertinggi pada pra-siklus sebesar 40 . Perolehan persentase skor terendah pada pra-siklus SRP sebesar 22 , FMPM sebesar 24 , IW sebesar 24, dan SHS sebesar 24. Pada siklus I skor yang diperoleh SRP sebesar 31, IW sebesar 32, SHS sebesar 32, dan FMPM sebesar 33, sedangkan pada siklus II diperoleh IW sebesar 40, SHS sebesar 42, dan SRP sebesar 42, perolehan persentase pada setiap siklusnya berbeda-beda. Hal ini dapat dipengaruhi oleh faktor intern dan ekstern diantaranya yaitu faktor bawaan atau keturunan, faktor minat dan pembawaan yang khas, faktor pembentukan atau lingkungan, faktor kematangan, dan faktor kebebasan, (Sujana et al., 2019).

Pada perolehan persentase skor tertinggi di pra-siklus, siklus I, dan siklus II yaitu ananda APZ dimungkinkan dipengaruhi oleh faktor-faktor pendukung tersebut di atas. Berdasarkan faktor keturunan, seperti belum dapat dinyatakan sebagai pendukung utama karena jika melihat latar belakang keluarga, APZ berasal dari keluarga yang berpendidikan, 
ayahnya berprofesi sebagai karyawan swasta lulusan S1, ibunya adalah seorang guru yang berlatar belakang S1. Jika dilihat dari faktor minat APZ memang memiliki minat atau ketertarikan yang besar terhadap aktivitas yang berkaitan dengan gambar (berdasarkan observasi selama penelitian). Menurut guru APZ adalah salah satu anak yang memiliki kreativitas yang baik. Orang tua APZ memang mendukung dan memfasilitasi minat atau kesukaan APZ melalui aktivitas menggambar, selain itu memberikan fasilitas pembelajaran yang lain di rumah seperti stimulasi pembelajaran berbagai macam media untuk mengembangkan kreativitas dan imajinasi APZ. Orang tua APZ juga sering mengajaknya diskusi atau berdialog serta mendampingi APZ ketika melakukan aktivitas bermain ataupun belajar. guru).

Pada perolehan persentase skor terendah oleh SRP disiklus I dan siklus II, dimungkinkan dipengaruhi oleh faktor-faktor pendukung tersebut di atas seperti halnya APZ namun berbeda pada kondisinya. Berdasarkan faktor keturunan, seperti belum dapat dinyatakan sebagai pendukung utama, namun jika kita melihat berdasarkan latar belakang keluarga, SRP berasal dari keluarga yang cukup berpendidikan, ayahnya berprofesi sebagai karyawan swasta dan ibunya sebagai ibu rumah tangga lulusan SMA (berdasarkan biodata anak). Jika dilihat dari faktor minat, SRP memang kurang memiliki minat dan ketertarikan yang besar terhadap gambar. SRP melakukan kegiatan montase tetapi ia cepat bosan, sering melamun, sibuk sendiri, sehingga tidak fokus pada saat aktivitas pembelajaran.jika dilihat dari faktor pembentukan atau lingkungan juga berkaitan dengan faktor kebebasan, orang tua SRP kurang memberikan ruang untuk SRP mengekspresikan daya imajinasinya dan kreativitasnya. Selain itu kurang memberikan sarana yang bermutu atau memfasilitasi dengan sarana pembelajaran yang kurang edukatif (berdasarkan informasi dari guru). di rumah SRP lebih sering menonton televisi. SRP jarang sekali melakukan kegiatan pembelajaran ataupun bermain dengan didampingi orang tuanya (berdasarkan informasi guru).

Hal tersebut dikarenakan anak-anak belum terbiasa melakukan kegiatan yang memiliki tujuan seperti kegiatan montase yang melibatkan berbagai indikator. Indikator yang bermasalah dari pra-siklus, siklus I, dan siklus II, seperti pada indikator menata ruang dan objek yang terlihat pada anak meliputi: kegiatan mendesain gambar menggunakan bentuk geometri, mengatur posisi gambar, sedangkan dalam melakukan kegiatan mendesain gambar dan mengatur posisi gambar masih membutuhkan stimulasi ketika memposisikan bentuk geometri serta latar gambar sehingga menciptakan suatu gambar yang menekankan indikator menata ruang dan objek.

Pada indikator mempunyai imajinasi yang baik terhadap gambar dan tulisan anak tidak dapat mengungkapkan imajinasi yang bisa terlihat dalam hasil karya anak. Kemudian indikator dengan media visual, dalam hal ini kegiatan dasar seperti mengenal bentuk dan mengenal warna dan sebagainya hampir semua anak mampu dan masih beberapa anak masih mengalami kekeliruan dalam membaca atau menjelaskan gambar. Sehingga pada siklus I dan siklus II, ditekankan pada 3 indikator ini agar lebih berkembang sesuai harapan atau secara optimal, sehingga kegiatan tersebut diulang hingga ke siklus II, agar anak lebih terbiasa dan lebih terlatih melakukan kegiatan yang melibatkan ketiga indikator yang dianggap sulit oleh anak.

Peningkatan Kecerdasan melalui kegiatan montase dalam kajian multidisiplin berkaitan dengan beberapa bidang ilmu seperti Pendidikan, Seni, Psikologi, Bahasa. Dalam ilmu pendidikan, kegiatan pembelajaran montase dipandang sebuah teknik yang digunakan dalam kegiatan belajar anak usia dini sesuai dengan hakikat belajar anak usia dini yaitu bermain karena melalui proses bermain semua aspek perkembangan anak terstimulasi, (Sonawat \& Gogri, 2008). Berkaitan dengan pendapat yang dikemukakan oleh (Mutiah \& Srikandi, 2021) bahwa bermain memungkinkan anak bereksplorasi terhadap berbagai kemungkinan yang ada. Bereksplorasi yang dimaksud anak dapat menuangkan segala ide dan imajinasi yang ada di dalam pikirannya ketika bermain, (Suharni et al., 2021). 
Dilihat dari sudut pandang seni, hal ini sangat mempengaruhi perkembangan seni anak, karena setiap kegiatan montase dapat meningkatkan imajinasi dan kreativitas anak. Hal ini berkaitan dengan pendapat (Rachmi \& Herdana, 2018) bahwa dalam bermain kreatif anak menggunakan imajinasinya, pikirannya, dan pertimbangannya untuk menciptakan sesuatu atau membuat kombinasi-kombinasi baru dai komponen-komponen alat permainan atau menggunakan bahan-bahan yang tidak terpakai lagi. Hasil penelitian (Al Fuad et al., 2017) yang menyatakan bahwa di dalam kegiatan montase anak-anak dapat membangun imajinasinya dalam menyusun gambar-gambar sehingga menjadi sebuah cerita yang baru.

Kajian penelitian ini dalam ilmu psikologi memberikan manfaat dan menciptakan imajinasi bentuk dalam pikirannya. Dalam hal ini, pemberian stimulasi menggunakan montase dapat mengembangkan kecerdasan visual spasial anak, karena menurut hasil penelitian (Farisha, 2019) stimulasi yang diberikan melalui kegiatan montase merupakan salah satu alternatif membangun aspek kecerdasan visual spasial anak.

Dalam bidang bahasa, berkaitan dengan proses komunikasi yang terjadi dalam proses kegiatan bermain montase. (Muri'ah \& Wardan, 2020) mengemukakan bahwa bahasa mencakup setiap sarana komunikasi dengan menyimbolkan pikiran dan perasaan untuk menyampaikan makna kepada orang lain. Berbahasa membutuhkan sebuah proses untuk menyampaikan apa yang akan dibahasakan, proses terbeut dinamakan sebuah komunikasi. Komunikasi itu sendiri adalah proses pengiriman dan penerimaan informasi, ide, perasaan, atau pesan, (Fauziddin, 2017). Fungsi komunikasi menurut (McErlean, 2018) adalah sebagai alat untuk melakukan interaksi sosial. Dengan demikian proses komunikasi yang terjadi ketika anak berinteraksi secara sosial dengan teman dan gurunya dalam kegiatan montase merupakan sebuah proses yang sedang dijalani anak dalam mengembangkan kemampuan berbahasanya. Hal tersebut sesuai dengan hasil penelitian (Faizah, 2019) dan (Desmareza, 2012) bahwa montase digeneralisasikan, dapat menumbuhkan aspek perkembangan social emosional anak, sehingga anak menjadi bagus aspek interaksinya dengan lingkungan social serta dapat mengontrol emosinya.

Teori perkembangan kecerdasan anak yang dikemukakan oleh (Hansen \& Stepputat, 2001) dalam penelitiannya yang menyebutkan bahwa perkembangan intelektual anak berkembang pesat pada tahun-tahun awal kehidupan anak terutama pada usia emas untuk dapat mengembangkan potensinya. Maka melalui kegiatan bermain potensi-potensi pada anak dapat terstimulasi sehingga potensi-potensi tersebut berkembang secara luas pada semua aspek. Oleh karena itu, sesuai dengan penelitian (Desmareza, 2012) bahwa kegiatan montase menjadi sarana bagi pengembangan kecerdasan anak.

Montase ini di samping meningkatkan kecerdasan visual spasial anak, juga turut mengembangkan aspek perkembangan fisik motoric anak, khususnya motoric halus. Sesuai dengan hasil penelitian yang dilakukan oleh Yulianto \& Awalia (2017) dengan judul Meningkatkan Kemampuan Motorik Halus Melalui Kegiatan Montase Pada Anak Kelompok B RA Al-Hidayah Nanggungan dan penelitian (Taznidaturrohmah et al., 2020) dengan juduln penelitian Upaya meningkatkan kemampuan motorik halus melalui kegiatan montase pada anak kelompok B di TK Dharma Wanita Dinoyo 01 Mojokerto.

Selanjutnya, kegiatan montase yang bisa memanfaatkan bahan daur ulang atau bahan bekas, membuat guru menjadi inovatif, hemat dan memiliki ide-ide baru dalam membuat media pembelajaran sesuai dengan hasil penelitian Nurharini \& Yuyarti (2020) yang berjudul pengembangan karya kolase, montase dan mozaik untuk meningkatkan kreativitas guru dalam pembelajaran, yang menghasilkan temuan bahwa guru menjadi kreatf setelah melakukan pembelajaran menggunakan montase.

Selama kegiatan berlangsung, peneliti memiliki beberapa keterbatasan. Di antaranya adalah Kelas yang diteliti hanya terbatas pada kelompok B usia 5-6 tahun, seharusnya kegiatan montase ini juga dapat dikembangkan pada anak usia dini yang ada di kelas awal. Penelitian dilakukan pada tengah semester kedua, sehingga jadwal pembelajaran disekolah lebih kearah persiapan kegiatan akhir tahun atau perpisahan. Hal ini membuat pemberian 
DOI: 10.31004/obsesi.v6i2.1624

tindakan tidak dapat dilakukan pada hari yang pasti atau berubah-ubah. Guru juga agak kewalahan dan perlu beradaptasi dengan kegiatan yang membuat anak lebih aktif, karena beberapa anak masih memerlukan bimbingan personal saat melakukan kegiatan. Serta keterbatasan peneliti dalam mendokumentasikan moment yang penting.

Terlepas dari kelemahan penelitian, hasil penelitian ini memberikan rekomendasi yang mendasar untuk keterlaksanaan pembelajaran di TK Universitas Riau khususnya dalam pengembangan aspek kecerdasan visual spasial anak. Melalui penelitian ini, terbahas beberapa hasil penelitian yang mengkaji metode lain untuk meningkatkan kecerdasan visual spasial anak, diantaranya penelitian Dewi (2020) tentang Meningkatkan Kecerdasan Visual Spasial Anak Melalui Kegiatan Di Laboratorium Visual Spasial. Penelitian Rosidah (2014) Peningkatan Kecerdasan Visual Spasial Anak Usia Dini Melalui Permainan Maze, Kemudian Karolina (2018) meningkatkan kecerdasan visual spasial anak Melalui Kegiatan Menggambar, kemudian Astuti (2019) melalui kegiatan kolase dari kepingan kulit telur, serta Abubakar \& Asni (2019) dengan hasil penelitiannya meningkatkan kecerdasan visual spasial anak melalui kegiatan Membuat Kolase Dengan Pasir Berwarna.

\section{SIMPULAN}

Kegiatan montase dapat meningkatkan kecerdasan visual spasial anak pada kelompok B TK Universitas Riau. Keberhasilan ini didukung dari hasil analisis data pra-siklus dengan perolehan persentase TCP pada siklus I dan pada siklus II meningkat atau berada pada kategori berkembang sesuai harapan (BSH) dan pada penelitian ini Sebagian besar anak sudah mencapai pada kategori berkembang sesuai harapan (BSH). Hasil yang diperoleh menunjukkan TCP kecerdasan visual spasial mencapai kriteria yang diharapkan. Sehingga diharapkan TK Universitas Riau khususnya dapat menerapkan kegiatan montase pada pembelajaran.

\section{UCAPAN TERIMA KASIH}

Penulis mengucapkan terimakasih kepada seluruh pihak yang sudah membantu dalam pelaksanaan penelitian, Guru, Kepala Sekolah dan Siswa kelas B TK Universitas Riau, pihak kampus dan rekan sejawat. Terimakasih juga untuk pengelola jurnal Obsesi yang berkenan menerbitkan naskah hasil penelitian ini.

\section{DAFTAR PUSTAKA}

Abubakar, S. R., \& Asni, A. (2019). Kegiatan Membuat Kolase Dengan Pasir Berwarna Dalam Meningkatkan Kemampuan Visual Spasial Anak. Jurnal Smart PAUD, 2(1), 76-82. https://doi.org/10.36709/jspaud.v2i1.5925

Al Fuad, Z., Helminsyah, H., \& Subhananto, A. (2017). Pengembangan Model Pembelajaran Montase Kreatif Dengan Teknik Lihat, Gunting, Tempel, Dan Ceritakan (LGTC) Untuk Meningkatkan Keterampilan Berbicara Siswa Sekolah Dasar. Visipena, 8(2), 280-294. https://doi.org/10.46244/visipena.v8i2.412

Armstrong, T. (2009). Multiple Intelligence in the Classroom 3rd Edition. ASCD Member Book.

Astuti, D. (2019). Peningkatan kecerdasan visual spasial anak melalui kegiatan kolase dari kepingan kulit telur kelompok a di RA Manda Wonosari Ngaliyan tahun 2018/2019. UIN Walisongo.

Chairilsyah, D. (2020). Improving the Visual Spatial Intelligence Puzzle Children Through Play in Group B3 Tk Trustees in State 1 Bangko District Rokan Hilir Meningkatkan Kecerdasan Visual Spasial Anak Melalui Bermain Puzzle Pada Kelompok B3. Jurnal Online Mahasiswa, 05(01), 18.

Desmareza, R. (2012). Peningkatan Perkembangan Sosial Emosional Anak Melalui Permainan Montase di RA Darul 'Ulum PGAI Padang. Jurnal Ilmiah Pesona PAUD, 1(2).

Dewi, H. S. (2020). Meningkatkan Kecerdasan Visual Spasial Anak Melalui Kegiatan Di Laboratorium Visual Spasial Pada Kelompok A Di Raudhatul Athfal Ulul Albab Mangli Jember Tahun 2020. Institut Agama Islam Negeri Jember. 
Faizah, S. (2019). Penerapan Teknik Montase Terhadap Perkembangan Daya Pikir Anak pada Pembelajaran Anak Usia Dini di RA Aisyiyah Al Tanbih Getas Pejaten Jati Kudus. IAIN KUDUS.

Farisha, I. (2019). Upaya meningkatkan kreativitas anak melalui kegiatan montase di kelompok A TKA As-Sunnah SKP. PAUD 0005. universitas Muhammadiyah Tasikmalaya.

Fauziddin, M. (2017). Upaya Peningkatan Kemampuan Bahasa Anak Usia 4-5 Tahun melalui Kegiatan Menceritakan Kembali Isi Cerita di Kelompok Bermain Aisyiyah Gobah Kecamatan Tambang. Jurnal Obsesi: Jurnal Pendidikan Anak Usia Dini, 1(1), 42-51. https://doi.org/10.31004/obsesi.v1i1.154

Hajar Pamadhi, E. S. S. (2008). Seni Keterampilan Anak. Universitas Terbuka.

Hansen, T. B., \& Stepputat, F. (2001). Introduction: States of imagination. Duke University Press. https://doi.org/10.1215/9780822381273-001

Huberman, A. M., \& Miles, J. S. M. B. (2019). Qualitative data analysis: A methods sourcebook.

Hyangsook, L. (2013). The Brain and Learning: Examining the Connection among Brain Activity, Intelligence, and Learning Outcomes in Visual Instruction [Kent State University]. https://eric.ed.gov/?id=ED568406

Karolina, L. (2018). Mengembangkan Kecerdasan Visual Spasial Melalui Kegiatan Menggambar Di Tk Sepakat Kecamatan Talo. Iain Bengkulu.

Laliberte, M. (2020). Collage, Montage, Assemblage: History and Contemporary Techniques by Norman $\begin{array}{lllll}\text { Laliberté, } & \text { Alex } & \text { Mogelon. } & \text { Leonardo, } & \text { 8(1), }\end{array}$ https://doi.org/10.2307/1573212

McErlean, K. (2018). Interactive narratives and transmedia storytelling: Creating immersive stories across new media platforms. https://doi.org/10.4324/9781315637570

Miswanto, M. (2014). Pengaruh Kecerdasan Visual-Spasial terhadap Kreativitas Siswa (p. 165). http:/ / repo.iain-tulungagung.ac.id/245/

Muharrar, S., \& Verayanti, S. (2013). Kreasi Kolase, montase, mozaik sederhana. Jakarta: Erlangga.

Muri'ah, D. R. H. S., \& Wardan, K. (2020). Psikologi Perkembangan Anak dan Remaja. Literasi Nusantara.

Mutiah, E., \& Srikandi, S. (2021). Konsep Pengembangan Kreativitas AUD. Buhuts Al-Athfal: Jurnal Pendidikan Dan Anak Usia Dini, 1(1), 1-15.

Naibaho, S., Indarto, W., \& Hukmi, H. (2017). Pengaruh Kegiatan Montase Terhadap Kemampuan Motorik Halus Anak Usia 5-6 Tahun di TK Tunas Melati Kandis, Kabupaten Siak. Riau University.

Nurharini, A., \& Yuyarti, Y. (2020). Pengembangan Karya Kolase, Montase dan Mozaik Untuk Meningkatkan Kreativitas Guru dalam Pembelajaran SBDP bagi Guru SD. JURNAL PANJAR: Pengabdian Bidang Pembelajaran, 2(1), 1-7.

Rachmi, T., \& Herdana, M. (2018). Optimalisasi Kreativitas Anak Melalui Aktivitas Montase pada Usia Taman Kanak-Kanak. Syntax Literate; Jurnal Ilmiah Indonesia, 3(3), 161-168.

Restian, A. (2020). Pendidikan Seni Rupa Estetik Sekolah Dasar (Vol. 1). UMMPress.

Rosidah, L. (2014). Peningkatan Kecerdasan Visual Spasial Anak Usia Dini Melalui Permainan Maze. Jurnal Pendidikan Usia Dini, 8(2), 281-290.

Sonawat, R., \& Gogri, P. (2008). Multiple Intelligences for Pre-school Children. Multi-Tech Publishing Co.

Suharni, S., Wahyuni, S., \& Astri, Y. (2021). Improving Environmental Care Attitudes of Early Childhood By Utilizing Recycled Materials. Jurnal Obsesi: Jurnal Pendidikan Anak Usia Dini, 5(2), 2017-2024. https:// doi.org/10.31004/obsesi.v5i2.783

Sujana, M. P. U., Syukri, A., \& Musa, M. (2019). Melalui Kegiatan Mencoret, Merobek dan Menempel (3M) Meningkatkan Keterampilan Motorik Halus Anak Autis Di Taman Kanak-Kanak Buah Hati Kota Jambi. UIN Sulthan Thaha Saifuddin Jambi.

Taznidaturrohmah, Y. E., Pramono, P., \& Suryadi, S. (2020). Upaya meningkatkan kemampuan motorik halus melalui kegiatan montase pada anak kelompok B di TK Dharma Wanita Dinoyo 01 Mojokerto. Jurnal Pendidikan 20-26. https://doi.org/10.21831/jpa.v9i1.29805

Yulianto, D., \& Awalia, T. (2017). Meningkatkan Kemampuan Motorik Halus Melalui Kegiatan Montase Pada Anak Kelompok B RA Al-Hidayah Nanggungan Kecamatan Prambon Kabupaten Nganjuk Tahun Pelajaran 2015/2016. Jurnal Penelitian Inovasi Pembelajaran, 2(2), 118-123. 